\title{
PREDIKSI TINGKAT KEKERUHAN (TURBIDITAS) MENGGUNAKAN CITRA SATELIT SENTINEL-2A DI WADUK JATILUHUR, JAWA BARAT
}

\section{PREDICTION OF WATER TURBIDITY USING SATELLITE IMAGERY SENTINEL-2A IN JATILUHUR RESERVOIR, WEST JAVA}

\author{
Arip Rahman ${ }^{1)^{*}}$ Lismining Pujiyani Astuti1) Andri Warsa') Agus Arifin Sentosa ${ }^{1)}$ \\ 1)Balai Riset Pemulihan Sumberdaya Ikan \\ Jl. Cilalawi No. 1 Jatiluhur Purwakarta Jawa Barat \\ *Correspondence Email: alphagrt79@gmail.com \\ Diterima: 27 November 2020; Direvisi: 24 Agustus 2021; Disetujui: 15 September 2021
}

\begin{abstract}
Turbidity is one of the remote sensing indicators on the reservoir physical characteristics that can reduce its brightness level. Measuring reservoir physical characteristics traditionally are expensive and time consuming as well. Therefore, remote sensing is used as an alternative for turbidity measurement because it can provide data and products spatially, temporally as well as synoptically with low cost. This study aims to obtain an algorithm using a combination of in-situ turbidity data measurement and Sentinel-2A satellite imagery data. The resulting algorithm can be used to predict and map turbidity in Jatiluhur Reservoir. Based on the multiregression between B3 (green band) and B4 (red band) with in-situ turbidity data measurement, it is obtainted that the regression coefficients are $a=76.77, b=63.22$ and $c=-34.31$ respectively, with the equation of $Y=76,77+63.22 X_{1}-34.31 X_{2}$ ( $Y=$ predicted turbidity, $\left.X_{1}=\ln B 3, X_{2}=\ln B 4\right)$. The correlation value between in situ and turbidity prediction is quite strong with a coefficient of determination $\left(R^{2}\right)$ of 0.60 , and Root Mean Square Error (RMSE) of 1.95 NTU. Based on Mean Absolute Percentage Error (MAPE) analysis, the deviation is $31.1 \%$. High levels of turbidity can reduce the main productivity of water and its organisms, especially in respiratory and visual problems. Sedimentation caused by high turbidity levels can make siltation which results in reservoir capacity loss.
\end{abstract}

Keywords: Turbidity, remote sensing, Sentinel-2A satellite imagery data, Jatiluhur Reservoir, siltation

\section{ABSTRAK}

Turbiditas merupakan salah satu indikator penginderaan jauh pada karakteristik fisik waduk yang dapat mengurangi tingkat kecerahan suatu perairan. Pengukuran karakteristik fisik danau secara tradisional memerlukan waktu dan biaya yang mahal. Oleh sebab itu, penginderaan jauh digunakan sebagai alternatif pengukuran turbiditas karena dapat menyediakan data dan produk secara spasial, temporal dan sinoptik dengan biaya murah. Penelitian bertujuan untuk mendapatkan persamaan algoritma dengan menggunakan kombinasi antara data turbiditas in situ di Waduk Jatiluhur dan data citra satelit Sentinel-2A. Persamaan algoritma yang dihasilkan dapat digunakan untuk memprediksi dan memetakan nilai turbiditas di Waduk Jatiluhur. Berdasarkan hasil multiregresi, kombinasi B3 (kanal hijau) dan B4 (kanal merah) dengan nilai turbiditas hasil pengukuran in situ diperoleh koefisien regresi $a=76,77, b=63,22$ dan $c=-34,31$, sehingga diperoleh persamaan $Y=76,77+63,22 X_{1}-34,31 X_{2}\left(Y=\right.$ turbiditas prediksi, $\left.X_{1}=\ln B 3, X_{2}=\ln B 4\right)$ Korelasi antara nilai turbiditas in situ dengan nilai turbiditas prediksi cukup kuat dengan koefisien determinasi $\left(R^{2}\right)=0,60$, dan Root Mean Square Error (RMSE) sebesar 1,95 NTU. Berdasarkan analisis Mean Absolute Percentage Error (MAPE), penyimpangan nilai turbiditas prediksi terhadap nilai turbiditas in situ sebesar 31,1\%. Tingkat kekeruhan yang tinggi dapat mengurangi produktivitas primer suatu perairan dan mengganggu organisme yang berada di dalamnya, terutama dalam masalah pernapasan dan penglihatan. Proses sedimentasi yang disebabkan oleh tingkat kekeruhan yang tinggi dapat menyebabkan terjadinya pendangkalan yang dapat mengakibatkan hilangnya kapasitas penyimpanan pada waduk

Kata Kunci: Turbiditas, penginderaan jauh, citra satelit Sentinel-2A, Waduk Jatiluhur, pendangkalan 


\section{PENDAHULUAN}

Danau atau waduk merupakan salah satu ekosistem air tawar yang menyediakan berbagai jasa ekosistem mulai habitat biota perairan, rekreasi dan irigasi (Stoddard et al., 2016). Pengoperasian dan pemanfaatan waduk harus memenuhi beberapa persyaratan sehingga fungsi waduk dapat dimanfaatkan dalam jangka panjang (Chamoun et al., 2017).

Berbagai tekanan ekologis seperti peningkatan tingkat kesuburan (eutrophication) dan perubahan iklim menjadi salah satu ancaman terhadap fungsi ekologis yang terdapat di danau (Dörnhöfer \& Oppelt, 2016). Hal lain yang dapat memperburuk kondisi suatu perairan adalah adanya pencemaran akibat limbah dari kegiatan penduduk (antropogenik) (KC et al., 2019; Zhao et al., 2016) dan terjadinya proses sedimentasi (Espa et al., 2016).

Skema monitoring yang berkelanjutan diperlukan untuk mengantisipasi ancaman terhadap fungsi ekologis waduk tersebut. Monitoring dan survei lapangan yang dilakukan secara tradisional memerlukan biaya yang mahal, waktu yang relatif lama dan tidak dapat menjangkau daerah yang sulit (Ismail et al., 2019; Kutser et al., 2016; Martins et al., 2017; Ouma et al., 2018). Diperlukan suatu upaya alternatif untuk monitoring real time dengan biaya yang cukup murah dan tidak membutuhkan waktu yang cukup lama (Boucher et.al., 2018). Data penginderaan jauh yang tersedia secara gratis menjadi alternatif untuk mendapatkan data spasial dan temporal untuk monitoring perairan yang luas dan daerah yang sulit dijangkau (Guo et al., 2017; Martins et al., 2017). Biaya operasional yang rendah dalam penggunaan data penginderaan menjadi dorongan bagi lembaga penelitian untuk melengkapi data dan menghasilkan peta distribusi spasial beberapa parameter kualitas air (Pizani et al., 2020).

Kekeruhan merupakan salah satu indikator karakteristik fisik danau dan waduk yang dapat dimonitor dengan penginderaan jauh. Kekeruhan merupakan ukuran kecerahan relatif pada suatu perairan yang menggambarkan properti optik yang menyebabkan cahaya tersebar dan diserap oleh partikel-partikel tersuspensi (Mullins et al., 2018). Kekeruhan berkorelasi dengan total padatan tersuspensi (TSS) dari limbah cair yang berupa massa partikulat dalam fluida (Hannouche et al., 2017). Pada saat kegiatan monitoring kualitas air, turbiditas merupakan salah satu parameter penting dalam penggolongan kualitas perairan, sebagai indikator adanya polusi dan performa suatu perairan (Castaño \& Higuita, 2016; Mullins et al., 2018). Tingkat kekeruhan perairan dapat mengurangi penetrasi cahaya ke dalam kolom air yang diperlukan untuk proses fotosintesis fotoplankton.

Beberapa penelitian dan monitoring tingkat kekeruhan yang menggunakan data penginderaan jauh antara lain, monitoring turbiditas menggunakan data citra satelit resolusi rendah Moderate Resolution Imaging Spectroradiometer (MODIS) di Bagre Reservoir Burkina Faso (Robert et al., 2016), pengembang model turbiditas untuk menilai turbiditas di waduk berdasarkan citra satelit Landsat 8 (Liu \& Wang, 2019), pengukuran tingkat kekeruhan menggunakan citra Landsat 5 di Aplachicola Bay (Joshi et al., 2017). Sementara itu, penelitian yang dilakukan pada kesempatan ini difokuskan pada salah satu karakteristik fisik danau yaitu tingkat kekeruhan yang diprediksi dengan menggunakan data citra satelit Sentinel-2A dan data lapangan (in situ) hasil pengukuran di Waduk Jatiluhur.

Waduk Jatiluhur merupakan bagian dari sistem waduk kaskade (waduk berjenjang) dari Sungai Citarum (Astuti et al., 2016) yang terletak di Kabupaten Purwakarta Jawa Barat. Waduk Jatiluhur menerima aliran air dari waduk yang ada di atasnya yaitu Waduk Saguling dan Waduk Cirata. Selain sebagai Pembangkit Listrik Tenaga Air, Waduk Jatiluhur digunakan sebagai arena rekreasi dan aktifitas perikanan dengan budidaya Keramba Jaring Apung (KJA). Berkembangnya usaha budidaya KJA berdampak terhadap perubahan kualitas air di Waduk Jatiluhur. Perubahan kualitas air yang pertama kali terpantau adalah tingkat kecerahan yang menurun. Pada tahun 1984 kecerahan air berkisar antara 1-4 m sedangkan pada tahun 2015 kecerahan air menurun hanya berkisar antara 0.4-2.9 m (Astuti, et al., 2016).

Penelitian bertujuan untuk mendapatkan persamaan algoritma untuk mengestimasi tingkat kekeruhan perairan pada musim peralihan (bulan Agustus) di Waduk Jatiluhur. Persamaan algoritma diperoleh berdasarkan korelasi antara nilai turbiditas hasil pengukuran in situ dengan nilai pantulan (reflectance) dari data citra Sentinel-2A. Data Citra Sentinel-2A diperoleh secara gratis dengan mengunduh pada situs yang menyediakan akses data penginderaan jauh salah satunya adalah USGS Global Visualization Viewer (GLOVIS), glovis.usgs.gov. Resolusi spasial dari citra Sentinel2A dapat mendeteksi badan air yang lebih sempit dengan minimum permukaan badan air yang dapat terdeteksi sekitar $100 \mathrm{~m}^{2}$ (Jin et al., 2017). Persamaan yang diperoleh selanjutnya akan digunakan untuk memetakan sebaran tingkat kekeruhan di perairan Waduk Jatiluhur. 


\section{METODOLOGI}

\section{Lokasi Penelitian}

Penelitian dilakukan di Waduk Jatiluhur Kabupaten Purwakarta dengan posisi geografis 6025'-6035' LS dan 107022'-107030' BT (Gambar 1). Luas genangan air Waduk Jatiluhur \pm 8300 ha dengan kedalaman rata-rata 37,6 m (Astuti et al., 2016). Selain fungsinya sebagai Pembangkit Listrik Tenaga Air (PLTA), Waduk Jatiluhur juga berfungsi sebagai sumber air untuk irigasi, industri dan air baku air minum serta pengendali banjir. Kegiatan perikanan dan pariwisata merupakan fungsi tambahan yang ada di Waduk Jatiluhur.

\section{Pengambilan Data Lapangan}

Data turbiditas diperoleh dari hasil pengukuran in situ dengan menggunakan Water Quality Checker (WQC) Horiba U-50 series pada bulan Agustus 2020. Diperoleh 25 titik pengukuran nilai turbiditas in situ yang tersebar di lokasi penelitian (Gambar 2). Posisi geografis dicatat pada saat pengukuran nilai turbiditas in situ dengan menggunakan Global Positioning System (GPS).
Data posisi geografis digunakan untuk mengekstrak nilai reflektansi dari citra satelit yang akan digunakan untuk memprediksi tingkat kekeruhan di lokasi penelitian. Hasil ekstraksi diperoleh pasangan data turbiditas dengan nilai reflektansi dari citra yang digunakan. Nilai koefisien determinasi digunakan untuk melihat seberapa besar variabel bebas (nilai reflektansi) dan variabel terkaitnya (nilai turbiditas). Nilai koefisien determinasi $\left(\mathrm{R}^{2}\right)$ mendekati 1 menandakan variabel bebas memiliki kemampuan dalam menjelaskan variasi variabel terikat. Tingkat hubungan antar variabel dapat dilihat dari interval koefisien (Nduru et al.,, 2014) (Tabel 1).

Tabel 1 Hubungan variabel berdasarkan interval koefisien

\begin{tabular}{cc}
\hline Interval Koefisien & Tingkat Hubungan \\
\hline $0,80-1,00$ & Sangat Kuat \\
$0,60-0,79$ & Kuat \\
$0,40-0,59$ & Cukup Kuat \\
$0,20-0,39$ & Rendah \\
$0,00-0,19$ & Sangat Rendah \\
\hline
\end{tabular}

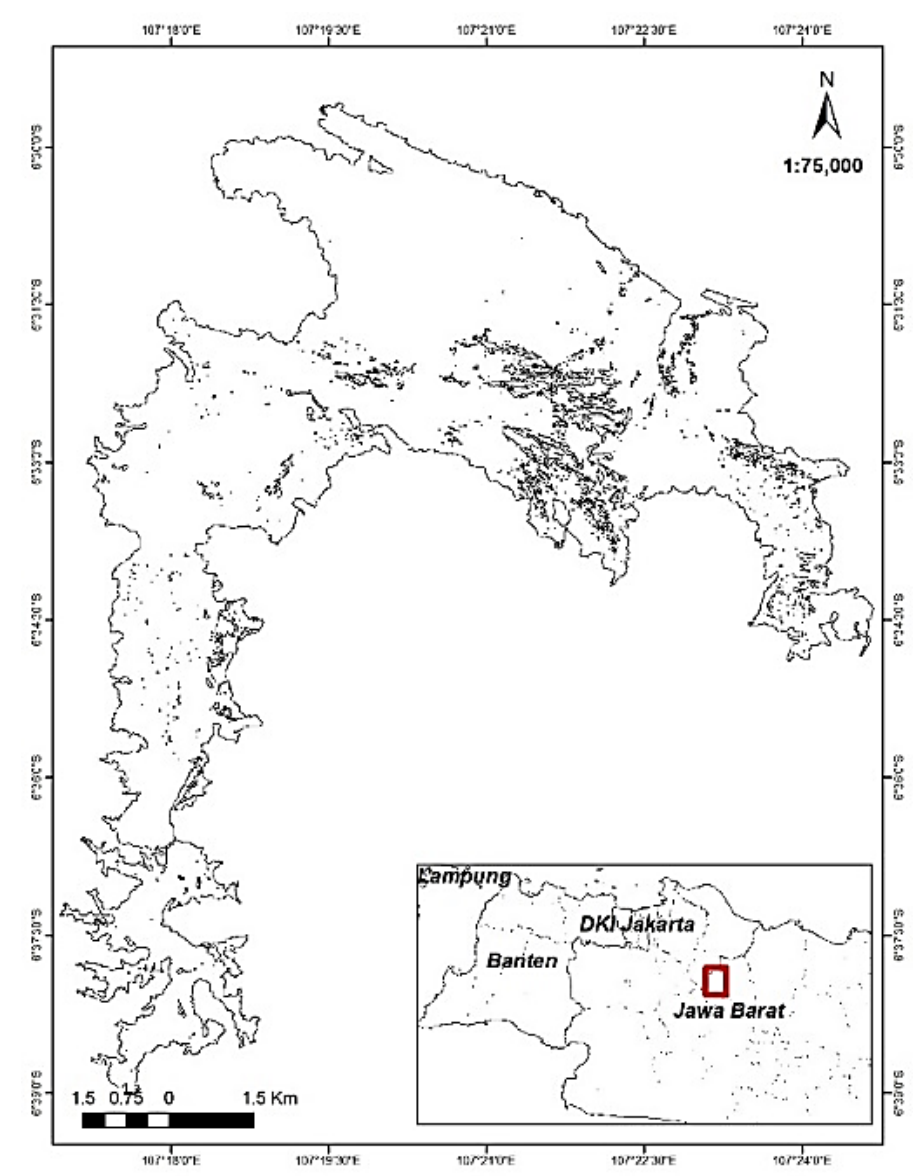

Gambar 1 Lokasi penelitian di Waduk Jatiluhur 


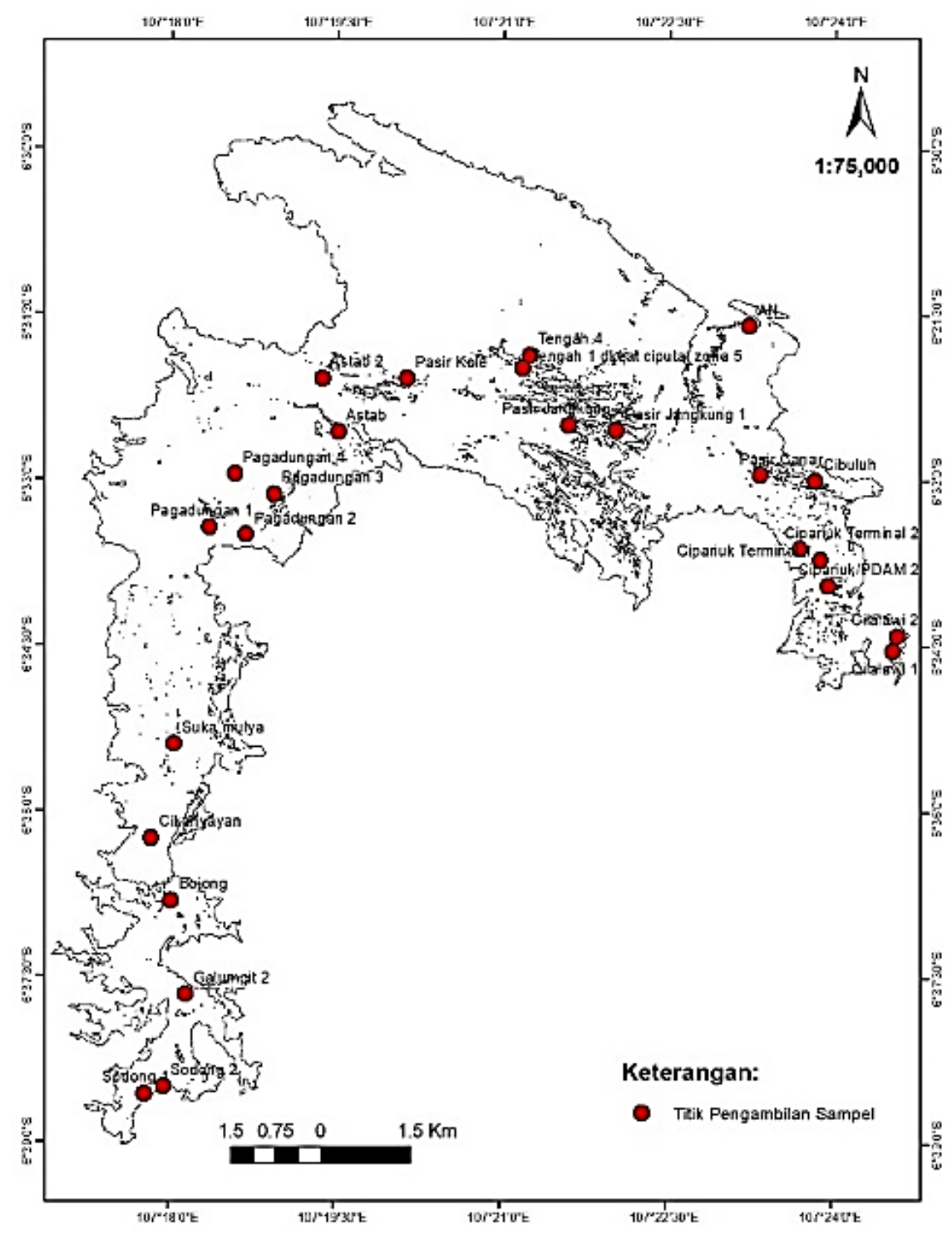

Gambar 2 Titik lokasi pengukuran turbiditas secara in situ

Data citra satelit yang digunakan dalam penelitian ini adalah citra satelit multispektral Sentinel-2A yang terdiri dari 13 kanal dengan tanggal akuisisi 7 Agustus 2020 (Tabel 2). Kanal yang digunakan dalam penelitian ini adalah kanal pada spektrum elektromagnetik sinar tampak dan inframerah dekat dengan resolusi spasial $10 \mathrm{~m}$ (Tabel 3). Hal tersebut sesuai dengan yang dikemukakan Dekker et al., 2002, bahwa untuk memperoleh informasi tentang properti danau seperti transparansi air, biota dan hidrologi, panjang gelombang yang digunakan adalah panjang gelombang sinar tampak dan inframerah dekat dengan kisaran panjang gelombang 400-900 nm.

\section{Alur Penelitian}

Data yang digunakan dalam penelitian ini adalah data citra satelit Sentinel-2A dan data tingkat kekeruhan (turbiditas) hasil pengukuran in situ (Gambar 3). Sebelum analisis lebih lanjut, praprosesing dilakukan terhadap data citra satelit dengan melakukan kalibrasi radiometrik dan kereksi atmosferik. Setelah itu dilakukan penyusunan persamaan algoritma yang hasilnya dapat digunakan untuk pembuatan peta sebaran turbiditas di danau dan waduk. 
Tabel 2 Spesifikasi data citra satelit Sentinel-2A

\begin{tabular}{cccc}
\hline Entity ID & Tanggal Akuisisi & Tutupan Awan & Platform \\
\hline L1C_T48MYT_A026770_20200807T030951 & $07 / 08 / 2020$ & $7,28 \%$ & SENTINEL-2A \\
\hline
\end{tabular}

Tabel 3 Spektrum elektromagnetik sinar tampak citra Sentinel-2A

\begin{tabular}{lcc}
\hline \multicolumn{1}{c}{ Kanal } & Kisaran Panjang Gelombang (nm) & Resolusi (m) \\
\hline B2 - Biru & $458-523$ & 10 \\
B3 - Hijau & $543-578$ & 10 \\
B4 - Merah & $650-680$ & 10 \\
B8 - NIR (Near Infrared) & $785-900$ & 10 \\
\hline
\end{tabular}

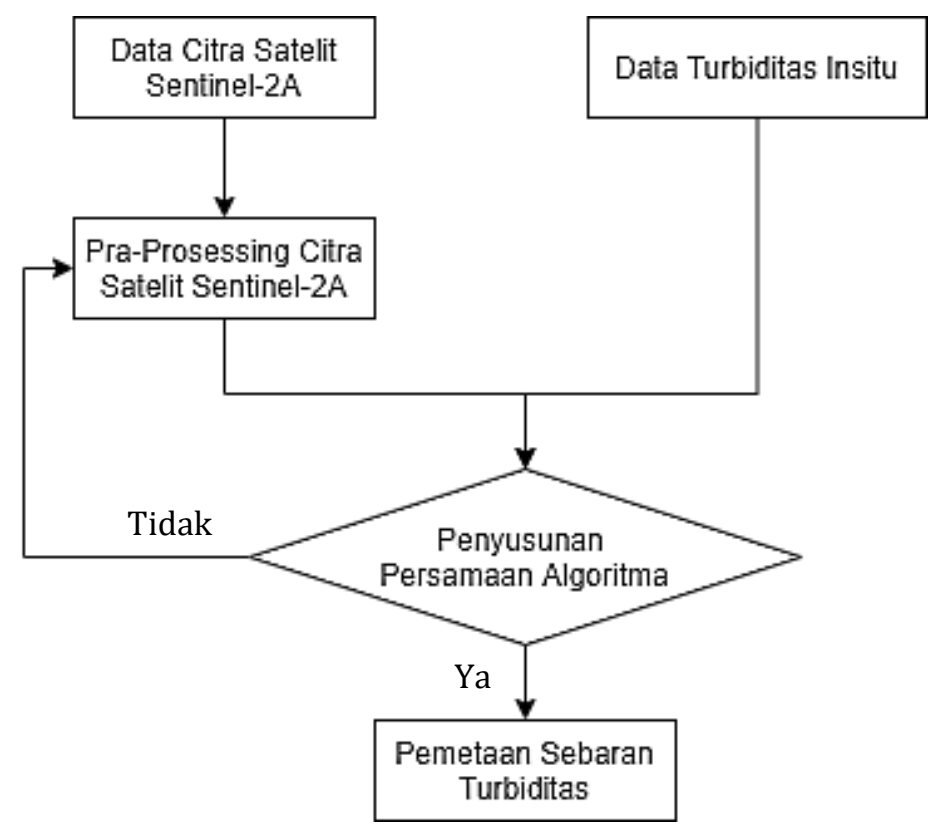

Gambar 3 Alur penelitian.

\section{Pra-Pemrosesan Data Satelit}

Pemotongan citra dilakukan sesuai dengan daerah penelitian yang kita lakukan untuk memperkecil kapasitas citra yang akan kita oleh. Selanjutnya dilakukan pemisahan kolom perairan dan daratan dengan menggunakan algoritma NDWI, untuk mengekstrak data yang terdapat pada kolom air.

Panjang gelombang yang digunakan dalam penelitian ini adalah panjang gelombang sinar tampak yaitu: biru (B2), hijau (B3), merah (B4) dan infrared (B8) yang terdapat pada citra Sentinel-2A. Pra-pemrosesan data dilakukan dengan melakukan koreksi terhadap data citra satelit. Kalibrasi radiometrik dilakukan dengan metode yang terdapat pada perangkat lunak Quantum GIS (QGIS). Nilai digital number (DN) dari setiap pixel image dan setiap spectral band dikonversi ke dalam nilai reflektansi.

Koreksi atmosferik dilakukan untuk mendapatkan data penginderaan jauh dengan kualitas baik untuk aplikasi kuantitatif dan memperoleh data beberapa parameter yang terdapat pada permukaan bumi. Dark Object Substraction (DOS) yang terintegrasi pada perangkat lunak QGIS digunakan untuk melakukan koreksi atmosferik. Koreksi atmosferik bertujuan untuk menghilangkan pengaruh dari komponen yang terdapat pada atmosfer seperti partikel padat dan uap air. 
Nilai reflektansi dari panjang gelombang yang terdapat pada citra kemudian di ekstrak sesuai dengan titik pengambilan data turbiditas lapangan. Setelah diperoleh pasangan data dari nilai reflektansi citra dan nilai turbiditas, pasangan data tersebut selanjutnya digunakan untuk pembuatan algoritma untuk memprediksi nilai turbiditas.

\section{Analisis}

Persamaan algoritma untuk menduga nilai turbiditas diperoleh dengan melakukan regresi antara nilai reflektansi citra kanal (B2, B3 dan B4) dengan nilai turbiditas yang diperoleh dari pengukuran secara in situ. Proses regresi dan multiregresi dilakukan secara trial and error untuk memperoleh kombinasi band yang menghasilkan nilai korelasi dan determinasi yang terbaik. Persamaan regresi dan multiregresi yang digunakan adalah

Persamaan regresi:

$y=a+b x$

dimana $a$ dan $b$ (koefisien yang diperoleh dari hasil regresi antara nilai reflektansi dan nilai turbiditas), $x$ (ln nilai reflektansi citra)

Persamaan multiregresi:

$y=a+b x_{1}+c x_{2}$

dimana a, b dan c (koefisien yang diperoleh dari hasil regresi antara nilai reflektansi dan nilai turbiditas), $\mathrm{x}_{1}$ dan $\mathrm{x}_{2}$ (In nilai reflektansi citra band ${ }_{i}$ ), $i=\mathrm{B} 1, \mathrm{~B} 2, \mathrm{~B} 3$.

Analisis statistik, Root Mean Square Error (RMSE), dilakukan untuk mengukur seberapa besar kesalahan yang terjadi di antara dua set data, yang membandingkan nilai prediksi dan nilai observasi yang diketahui. Semakin kecil nilai RMSE semakin dekat antara nilai prediksi dan nilai observasi. Persamaan yang digunakan yaitu

$R M S E\left(Y_{\text {pred }}, Y_{o b s}\right)=\sqrt{\frac{1}{n} \sum_{i=a}^{n}\left(Y_{\text {pred }}-Y_{o b s}\right)^{2}}$

dimana, $Y_{\text {pred }}=$ nilai turbiditas hasil prediksi, $Y_{o b s}=$ nilai turbiditas hasil pengukuran in situ, $\mathrm{n}=$ banyaknya sampel.

Analisis Mean Absolute Percentage Errors (MAPE) digunakan untuk mengukur ketepatan relatif yang digunakan untuk mengetahui persentase penyimpangan hasil prediksi.

$\operatorname{MAPE}\left(Y_{\text {obs }}, Y_{\text {pred }}\right)=\left(\frac{1}{n} \sum\left(\frac{\left|Y_{\text {obs }}-Y_{\text {pred }}\right|}{Y_{\text {obs }}}\right)\right) \times 100 .$.

\section{HASIL DAN PEMBAHASAN}

\section{Nilai Turbiditas}

Kisaran nilai turbiditas in situ dan prediksi disajikan pada Tabel 4. Pada Tabel 4 terlihat bahwa nilai turbiditas hasil prediksi lebih rendah daripada hasil pengukuran in situ. Hal tersebut diduga disebabkan oleh kombinasi kanal (ln B3 dan ln B4) yang digunakan dalam model prediksi yang menyebabkan nilai turbiditas prediksi menjadi lebih kecil (under estimate). Lokasi yang memiliki nilai turbiditas tinggi berada dekat dengan daratan dan memiliki kedalaman yang dangkal yaitu di daerah Cilalawi 1. Sementara itu lokasi yang memiliki nilai turbiditas rendah berada di tengah waduk pada perairan yang dalam yaitu daerah Pasir Canar (Gambar 2). Kekeruhan pada suatu perairan bisa disebabkan oleh adanya bahan organik, anorganik dan organisme renik (plankton) yang tersuspensi dan terlarut (Davis \& Cornwell, 2008). Bahan organik dan anorganik yang masuk ke perairan bisa disebabkan oleh adanya aliran (run off) dari daratan yang membawa serta lumpur dan pasir halus yang dapat mengakibatkan sedimentasi di dasar perairan. Beban sedimen yang terbawa oleh aliran air dapat merugikan ekosistem air tawar yang ada di bagian hilirnya, salah satunya dapat mengakibatkan kematian ikan (Baoligao et al., 2016). Sementara itu melimpahnya plankton di perairan disebabkan oleh meningkatnya kesuburan perairan. Kekeruhan yang tinggi yang disebabkan oleh bahan organik dan anorganik dapat mempengaruhi penetrasi cahaya matahari yang akan menghambat proses fotosintesis pada kolom air.

Tabel 4. Kisaran nilai turbiditas in situ dan prediksi

\begin{tabular}{l|c|c}
\hline & $\begin{array}{c}\text { Turbiditas in situ } \\
\text { (NTU) }\end{array}$ & $\begin{array}{c}\text { Turbiditas } \\
\text { Prediksi (NTU) }\end{array}$ \\
\hline Minimum & 3,10 & 2,47 \\
\hline Maksimum & 18,20 & 12,78 \\
\hline Rata-rata & 5,25 & 5,25 \\
\hline
\end{tabular}

\section{Algoritma Prediksi Nilai Turbiditas}

Regresi dan multiregresi antara kombinasi nilai reflektansi dengan nilai turbiditas hasil pengukuran lapangan (in situ) dilakukan untuk memperoleh hubungan kombinasi terbaik yang ditandai dengan nilai korelasi dan determinasi yang tinggi (Tabel 5). Berdasarkan hasil perhitungan yang terdapat pada Tabel 5, kombinasi multiregresi kanal 3 (B3) dan kanal 4 (B4) memiliki nilai koefisien determinasi tertinggi $\left(R^{2}=0,60\right)$. Tahap selanjutnya kombinasi B3 dan B4 digunakan dalam persamaan algoritma. 
Berdasarkan hasil multiregresi, kombinasi B3 dan B4 dengan nilai turbiditas hasil pengukuran diperoleh koefisien regresi $a=76,77 ; b=63,22$ dan $\mathrm{c}=-34,31$. Berdasarkan nilai koefisien regresi yang dihasilkan, persamaan empiris untuk memprediksi nilai turbiditas di perairan waduk Jatiluhur adalah:

$$
Y=76.77+63.22 X_{1}-34.31 X_{2}
$$

Dimana, $\mathrm{Y}=$ turbiditas hasil prediksi, $X_{1}(\ln \mathrm{B} 3), \mathrm{X}_{2}$ (ln B4)

Dapat dilihat nilai turbiditas prediksi pada setiap stasiun pengukuran ada yang yang lebih tinggi (over estimate) dan lebih rendah (under estimate) terhadap nilai turbiditas hasil pengukuran in situ. Penyimpangan nilai turbiditas antara data in situ dan prediksi diduga disebabkan oleh adanya perbedaan jenis partikel tersuspensi disetiap lokasi pengukuran turbiditas in situ yang menyebabkan perbedaan nilai reflektansi yang ditangkap oleh sensor satelit. Hal tersebut disebabkan karena jenis partikel tersuspensi memiliki daya serap (absorption) dan daya pantul (replectance) yang berbeda (Ogashawara et al., 2013).

Korelasi antara nilai turbiditas in situ dengan nilai turbiditas prediksi cukup kuat dengan koefisien determinasi $\left(\mathrm{R}^{2}=0,60\right)$. Hasil korelasi tersebut sedikit lebih baik dari hasil penelitian (Wang et.al., 2006), yang menggunakan persamaan multiregresi dengan data citra Landsat $-5\left(R^{2}=0,53\right)$. Namun nilai $\mathrm{R}^{2}$ tersebut lebih kecil dibandingkan hasil penelitian Liu \& Wang, 2019, pada saat membangun model turbiditas di Tseng-Wen and Nan-Hwa Reservoirs dengan menggunakan citra Landsat- 8 yang menghasilkan nilai $\mathrm{R}^{2}=0,727$. Hal tersebut kemungkinan dipengaruhi oleh perbedaan citra satelit yang digunakan (Landsat-5, Landsat-8 dan Sentinel-2A) dan waktu pengambilan data citra satelit tersebut. Koefisien determinasi mengambarkan seberapa besar kemampuan variabel bebas $\left(\mathrm{X}_{1}\right.$ dan $\left.\mathrm{X}_{2}\right)$ dalam menjelaskan varians dari variabel terikatnya $(\mathrm{Y})$.

Tabel 5 Koefisien korelasi $(r)$ dan koefisien determinasi $\left(R^{2}\right)$ hasil regresi antara kombinasi nilai reflektansi dan nilai turbiditas hasil pengukuran lapangan.

\begin{tabular}{c|c|c|c|c}
\hline \multirow{2}{*}{ Kombinasi } & \multicolumn{2}{c}{ Regresi Linear (ratio band) } & \multicolumn{2}{c}{ Multiregresi Linear (kombinasi 2 band) } \\
\cline { 2 - 5 } & $\mathrm{r}$ & $\mathrm{R}^{2}$ & - & $\mathrm{R}^{2}$ \\
\hline $\ln \mathrm{B} 2$ & 0,38 & 0,15 & - & - \\
\hline $\ln \mathrm{B} 3$ & 0,61 & 0,37 & - & - \\
\hline $\ln \mathrm{B} 4$ & 0,41 & 0,16 & - & - \\
\hline $\ln \mathrm{B} 8$ & 0,26 & 0,06 & 0,75 & 0,57 \\
\hline $\ln \mathrm{B} 2, \ln \mathrm{B} 3$ & 0,76 & 0,57 & 0,4 & $0 ., 6$ \\
\hline $\ln \mathrm{B} 2, \ln \mathrm{B} 4$ & 0,37 & 0,13 & 0,38 & 0,15 \\
\hline $\ln \mathrm{B} 2, \ln \mathrm{B} 8$ & 0,16 & 0,02 & 0,77 & 0,6 \\
\hline $\ln \mathrm{B} 3, \ln \mathrm{B} 4$ & 0,21 & 0,04 & 0,65 & 0,43 \\
\hline $\ln \mathrm{B} 3, \ln \mathrm{B} 8$ & 0,01 & 0,0001 & 0,43 & 0,18 \\
\hline $\ln \mathrm{B} 4, \ln \mathrm{B} 8$ & 0,07 & 0,006 & & - \\
\hline
\end{tabular}

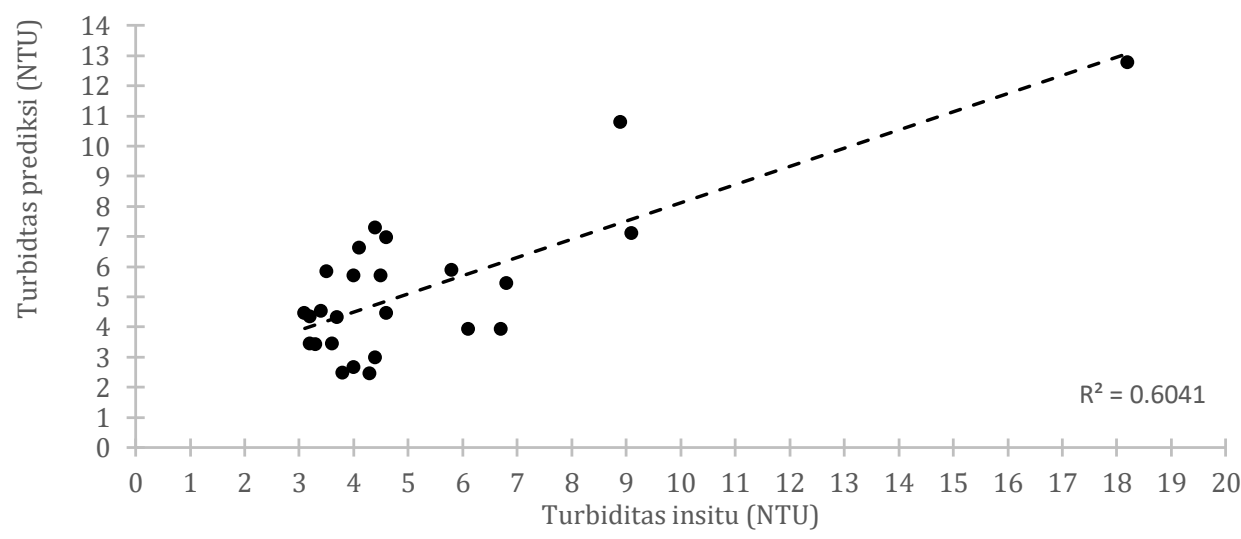

Gambar 4 Hubungan antara turbiditas in situ dan prediksi 
Nilai RMSE yang diperoleh berdasarkan hasil perhitungan sebesar 1,95 NTU, yang menggambarkan seberapa besar nilai kesalahan yang terjadi diantara dua set data (data in situ dan data prediksi). Grafik hubungan antara nilai turbiditas in situ dan nilai turbiditas prediksi dijelaskan pada Gambar 4. Berdasarkan analisis MAPE, penyimpangan nilai turbiditas prediksi terhadap nilai turbiditas in situ sebesar 31,1\% yang digambarkan pada Gambar 5.

\section{Peta Sebaran Tingkat Kekeruhan}

Model persamaan algoritma yang dihasilkan untuk memprediksi nilai turbiditas dapat digunakan untuk menggambarkan prediksi sebaran tingkat kekeruhan di Waduk Jatiluhur (Gambar 6). Setelah diketahuinya sebaran tingkat kekeruhan pada suatu badan air, perlu dilakukan kajian lanjutan untuk mengetahui faktor yang menyebabkan terjadinya kekeruhan tersebut, apakah disebabkan oleh bahan organik dan anorganik atau disebabkan oleh mikroorganisme yang tersuspensi di perairan. Kekeruhan pada perairan tergenang lebih banyak disebabkan oleh bahan tersuspensi yang berupa koloid dan partikelpartikel halus (Effendi, 2003).
Peningkatan turbiditas sebesar 5 NTU di perairan danau dapat mengurangi produktifitas primer sebesar 75\% (Effendi, 2003). Perairan dengan tingkat kekeruhan yang tinggi akan mengganggu pernafasan dan penglihatan organisme yang ada di dalamnya. Tingkat kekeruhan yang tinggi juga dapat mengakibatkan terjadinya sedimentasi dengan adanya proses pengendapan. Proses sedimentasi yang terjadi dapat mengakibatkan hilangnya kapasitas penyimpanan tanggul di waduk (Grobbelaar, 2009). Salah satu contoh hilangnya kapasitas penyimpanan terjadi di Bendungan Welbedacht, Afrika Selatan yang kehilangan 38\% kapasitas penyimpanannya dalam jangka waktu 3 tahun pertama setelah selesai pembuatan.

Berdasarkan gambaran dari peta prediksi sebaran turbiditas di Waduk Jatiluhur, di perairan bagian tengah yang dalam, tingkat kekeruhannya lebih rendah dibandingkan pada bagian pinggir perairan pada cekungan yang memiliki kedalaman dangkal. Tingginya kekeruhan pada bagian pinggir perairan diduga adanya pengaruh aliran (run off) dari daratan.

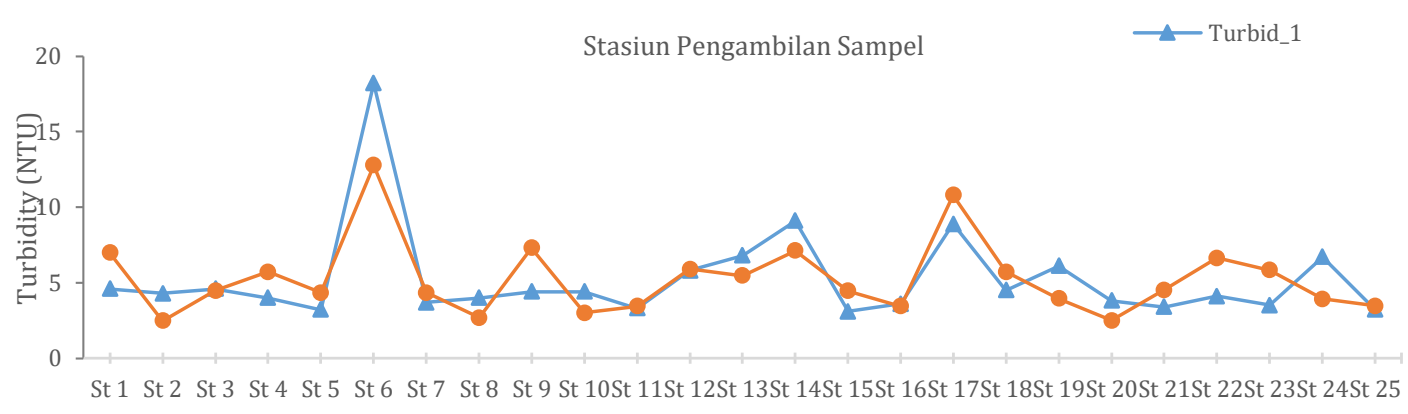

Gambar 5 Gambaran penyimpangan nilai turbiditas prediksi dan nilai turbiditas in situ

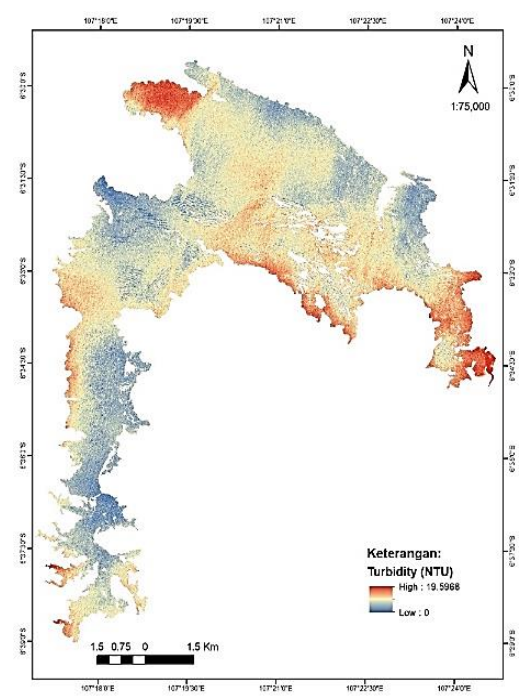

Gambar 6 Peta prediksi sebaran nilai turbiditas di Waduk Jatiluhur (Agustus 2020) 


\section{KESIMPULAN}

Persamaan algoritma untuk menduga tingkat kekeruhan pada musim peralihan di Waduk Jatiluhur dengan pendekatan persamaan multiregresi antara kombinasi B3 (kanal hijau) dan B4 (kanal merah) citra satelit Sentinel-2A dengan nilai turbiditas in situ adalah $\mathrm{Y}=76,77+63,22 \mathrm{X}_{1}$ $34,31 \mathrm{X}_{2}\left(\mathrm{Y}=\right.$ turbiditas prediksi, $\left.\mathrm{X}_{1}=\ln B 3, \mathrm{X}_{2}=\ln \mathrm{B} 4\right)$.

Korelasi antara nilai turbiditas in situ dengan nilai turbiditas prediksi cukup kuat dengan nilai koefisien determinas $\left(\mathrm{R}^{2}\right)=0,60$ dan RMSE 1,95 NTU. Hasil analisis MAPE, persentasi penyimpangan data hasil prediksi terhadap hasil pengukuran sekitar 31,1\%.

\section{UCAPAN TERIMA KASIH}

Ucapan terima kasih penulis sampaikan kepada Kepala Balai Riset Pemulihan Sumber Daya Ikan, BRSDM-KP, Ibu Iswari Ratna Astuti, kepada Penanggung Jawab kegiatan penelitian di Waduk Jatiluhur, Ibu Lismining Pujiyani Astuti beserta tim peneliti dan teknisi yang terlibat dalam kegiatan penelitian ini, serta kepada rekan penulis atas kerjasama dan diskusinya dalam penyusunan karya tulis ilmiah ini.

\section{DAFTAR PUSTAKA}

Astuti, Lismining Pujiyantiurfiarini, A., Sugianti, Y., Warsa, A., Rahman, A., \& Hendrawan, A. L. S. (2016). Tata Kelola Perikanan Berkelanjutan di Waduk Jatiluhur. (J. Haryadi, E. . Kartamihardja, Krismono, D. W. . Tjahjo, \& K. Amri, Eds.), Penerbit Deepublish. Yogyakarta: PENERBIT DEEPUBLISH.

Baoligao, B., Xu, F., Chen, X., Wang, X., \& Chen, W. (2016). Acute impacts of reservoir sediment flushing on fishes in the Yellow River. Journal of Hydro-Environment Research, 13, 26-35. https://doi.org/10.1016/j.jher.2015.11.003

Boucher, J., Weathers, K. C., Norouzi, H., \& Steele, B. (2018). Assessing the effectiveness of Landsat 8 chlorophyll a retrieval algorithms for regional freshwater monitoring. Ecological Applications, 28(4), 1044-1054. https://doi.org/10.1002/eap.1708

Castaño, J. A., \& Higuita, J. C. (2016). Using turbidity for designing water networks. Journal of Environmental Management, 172, 129-135. https://doi.org/10.1016/j.jenvman.2016.02.02 7

Chamoun, S., De Cesare, G., \& Schleiss, A. J. (2017). Management of turbidity current venting in reservoirs under different bed slopes. Journal of Environmental Management, 204, 519-530. https://doi.org/10.1016/j.jenvman.2017.09.03
0

Davis, M. ., \& Cornwell, D. . (2008). Introduction to Environtmental Engineering (Fourth Edi, Vol. 7). New: Mc Graw Hill, Inc.

Dekker, A. G., Brando, V. E., Anstee, J. M., Pinnel, N., Kutser, T., Hoogenboom, E. J., ... Malthus, T. J. M. (2002). Imaging Spectrometry of Water, (June 2014), 307-359. https://doi.org/10.1007/978-0-306-475788_11

Dörnhöfer, K., \& Oppelt, N. (2016). Remote sensing for lake research and monitoring - Recent advances. Ecological Indicators, 64, 105-122. https://doi.org/10.1016/j.ecolind.2015.12.009

Effendi, H. (2003). Telaah Kualitas Air Bagi Pengelolaan Sumberdaya dan Lingkungan Perairan. Yogyakarta: Penerbit Kanisius.

Espa, P., Brignoli, M. L., Crosa, G., Gentili, G., \& Quadroni, S. (2016). Controlled sediment flushing at the Cancano Reservoir (Italian Alps): Management of the operation and downstream environmental impact. Journal of Environmental Management, 182, 1-12. https://doi.org/10.1016/j.jenvman.2016.07.02 1

Grobbelaar, J. U. (2009). Encyclopedia of Inland Waters. Encyclopedia of Inland Waters, 699$704 . \quad$ Retrieved from http://www.sciencedirect.com/science/article /pii/B9780123706263000752

Guo, M., Li, J., Sheng, C., Xu, J., \& Wu, L. (2017). A review of wetland remote sensing. Sensors (Switzerland), 17(4), 1-36. https://doi.org/10.3390/s17040777

Hannouche, A., Joannis, C., \& Chebbo, G. (2017). Assessment of total suspended solids (TSS) event load and its uncertainties in combined sewer system from continuous turbidity measurements. Urban Water Journal, 14(8), 789-796.

https://doi.org/10.1080/1573062X.2016.1254 256

Ismail, K., Boudhar, A., Abdelkrim, A., Mohammed, H., Mouatassime, S., Kamal, A., ... Nouaim, W. (2019). Evaluating the potential of Sentinel-2 satellite images for water quality characterization of artificial reservoirs: The Bin El Ouidane Reservoir case study (Morocco). Meteorology Hydrology and Water Management, 7(1). https://doi.org/10.26491/mhwm/95087

Jin, H., Huang, C., Lang, M. W., Yeo, I. Y., \& Stehman, S. V. (2017). Monitoring of wetland inundation 
dynamics in the Delmarva Peninsula using Landsat time-series imagery from 1985 to 2011. Remote Sensing of Environment, 190, 26-41. https://doi.org/10.1016/j.rse.2016.12.001

Joshi, I. D., D'Sa, E. J., Osburn, C. L., \& Bianchi, T. S. (2017). Turbidity in Apalachicola Bay, Florida from Landsat 5 TM and field data: Seasonal patterns and response to extreme events. Remote Sensing, 9(4), 1-27. https://doi.org/10.3390/rs9040367

KC, A., Chalise, A., Parajuli, D., Dhital, N., Shrestha, S., \& Kandel, T. (2019). Surface Water Quality Assessment Using Remote Sensing, Gis and Artificial Intelligence. Technical Journal, 1(1), 113-122.

https://doi.org/10.3126/tj.v1i1.27709

Kutser, T., Paavel, B., Verpoorter, C., Ligi, M., Soomets, T., Toming, K., \& Casal, G. (2016). Remote sensing of black lakes and using $810 \mathrm{~nm}$ reflectance peak for retrieving water quality parameters of optically complex waters. Remote Sensing, 8(6). https://doi.org/10.3390/rs8060497

Liu, L. W., \& Wang, Y. M. (2019). Modelling reservoir turbidity using Landsat 8 satellite imagery by gene expression programming. Water (Switzerland), 11(7). https://doi.org/10.3390/w11071479

Martins, V. S., Barbosa, C. C. F., de Carvalho, L. A. S., Jorge, D. S. F., Lobo, F. de L., \& de Moraes Novo, E. M. L. (2017). Assessment of atmospheric correction methods for sentinel-2 MSI images applied to Amazon floodplain lakes. Remote Sensing,

9(4). https://doi.org/10.3390/rs9040322

Mullins, D., Jones, E., Glavin, M., Coburn, D., Hannon, L., \& Clifford, E. (2018). A novel image processing-based system for turbidity measurement in domestic and industrial wastewater. Water Science and Technology, 77(5), 1469-1482. https://doi.org/10.2166/wst.2018.030

Nduru, R. E., Situmorang, M., \& Tarigan, G. (2014). Analisa Faktor-Faktor Yang Mempengaruhi Hasil Produksi Padi Di Deli Serdang. Saintia Matematika, 2(1), 71-83.

Ogashawara, I., Mishra, D. R., Mishra, S., Curtarelli, M. P., \& Stech, J. L. (2013). A performance review of reflectance based algorithms for predicting phycocyanin concentrations in inland waters. Remote Sensing, 5(10), 4774-4798. https://doi.org/10.3390/rs5104774
Ouma, Y. O., Waga, J., Okech, M., Lavisa, O., \& Mbuthia, D. (2018). Estimation of Reservoir BioOptical Water Quality Parameters Using Smartphone Sensor Apps and Landsat ETM+: Review and Comparative Experimental Results. Journal of Sensors, 2018(August). https://doi.org/10.1155/2018/3490757

Pizani, F. M. C., Maillard, P., Ferreira, A. F. F., \& De Amorim, C. C. (2020). Estimation of water quality in a reservoir from sentinel-2 $\mathrm{msi}$ and landsat-8 oli sensors. ISPRS Annals of the Photogrammetry, Remote Sensing and Spatial Information Sciences, 5(3), 401-408. https://doi.org/10.5194/isprs-Annals-V-32020-401-2020

Robert, E., Grippa, M., Kergoat, L., Pinet, S., Gal, L., Cochonneau, G., \& Martinez, J. M. (2016). Monitoring water turbidity and surface suspended sediment concentration of the Bagre Reservoir (Burkina Faso) using MODIS and field reflectance data. International Journal of Applied Earth Observation and Geoinformation, 52(June), 243-251. https://doi.org/10.1016/j.jag.2016.06.016

Stoddard, J. L., Van Sickle, J., Herlihy, A. T., Brahney, J., Paulsen, S., Peck, D. V., ... Pollard, A. I. (2016). Continental-Scale Increase in Lake and Stream Phosphorus: Are Oligotrophic Systems Disappearing in the United States? Environmental Science and Technology, 50(7), 3409-3415. https://doi.org/10.1021/acs.est.5b05950

Wang, F., Han, L., Kung, H. T., \& van Arsdale, R. B. (2006). Applications of Landsat-5 TM imagery in assessing and mapping water quality in Reelfoot Lake, Tennessee. International Journal of Remote Sensing, 27(23), 5269-5283. https://doi.org/10.1080/01431160500191704

Zhao, Q., Bai, J., Huang, L., Gu, B., Lu, Q., \& Gao, Z. (2016). A review of methodologies and success indicators for coastal wetland restoration. Ecological Indicators, 60(April 2020), 442-452. https://doi.org/10.1016/j.ecolind.2015.07.003 